\title{
Indirect Vector Control of Multi Cage Induction Motor
}

\author{
Neelakantha Guru \\ Silicon Institute of Technology \\ Department of EEE \\ Bhubaneswar, Odisha.
}

\author{
Santosh Kumar Mishra \\ Krupajal Engineering College \\ Department of Electrical \\ Engineering \\ Bhubaneswar, Odisha
}

\author{
B. Nayak \\ KIIT University \\ School of Electrical Engineering \\ Bhubaneswar, Odisha.
}

\begin{abstract}
This paper presents a methodology for indirect vector control of a double cage induction motor. Vector control or field oriented control offers more precise control of high performance drives where oscillations in air gap flux linkages are intolerable. The mathematical model of a double cage induction machine is proposed. The developed model is studied with constant V/f control taking the boost voltage into account and indirect vector control. A comparison is made between the two control methods. Finally Simulation results have shown better results with indirect vector control compared to constant V/f control.
\end{abstract}

\section{General Terms}

Double-cage induction machine model, Indirect vector control, constant V/f control.

\section{Keywords}

Double cage induction motor, constant V/f control, Indirect vector control,.

\section{INTRODUCTION}

Induction machines with double cage rotor winding are commonly utilized in medium and high power applications. In applications that require high starting torque double-cage induction machine is preferred. Mathematical modeling approach for double-cage or deep-bar type induction machine is same. Representation of the rotor with two rotor windings rather than with a single winding is known to lead to significant improvement in the accuracy of simulation results for both deep-bar and double-cage induction machines[1]. The squirrel cage induction motor may be modeled with a double cage model in order to predict well starting current and torque [2]. The goal of this paper is to study the speed control of the squirrel-induction machine with a double cage model, by usingconstant $\mathrm{V} / \mathrm{f}$ control strategy. A new approach i.e. indirect vector controlwith boost voltage is proposed. Finally comparative simulation results of double cage model of squirrel cage induction motor withconstant volts $/ \mathrm{Hz}$ and indirect vector control is discussed.

\subsection{MODELOF} DOUBLECAGEINDUCTION MACHINE

The induction machine is often modeled with the single-cage model. However, this model is only acceptable for the wound rotor induction motors [2].

Single-cage type induction machines should be modeled with a double cage model. Deep, narrow rotor bars can be taken into account with this model because they have torque-speed characteristics similar to those of double-cage rotors. So that, single-cage rotor has been modeled, to take into account the skin effect which is very pronounced at starting conditions, with a double-cage model.

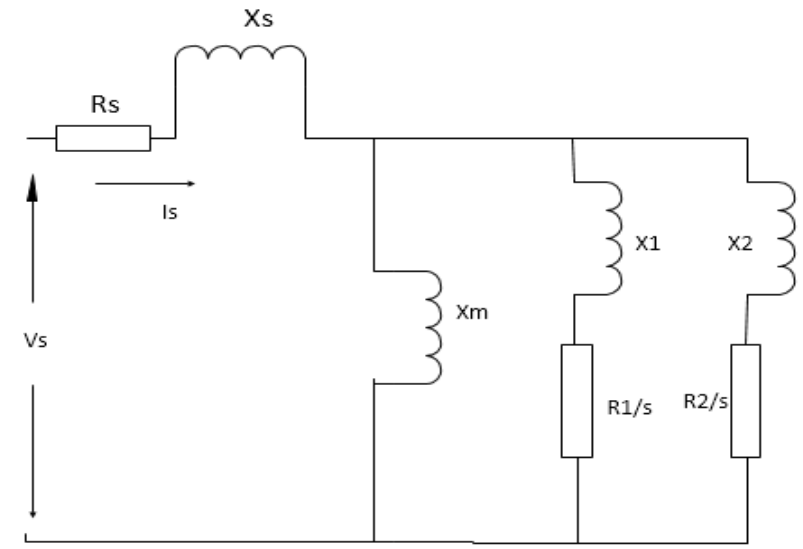

Fig 1: Equivalent circuit of double-cage induction motor

The mathematical model of a double-cage induction machine is arranged in a manner which is closely similar to the derivation of the $(d, q)$ model of a single-cage induction machine. Due to the additional second cage, the rotor is now described with four differential equations in a reference frame fixed in a stator as shown in Figure 2. The symbols used through the paper are defined in the Nomenclature.

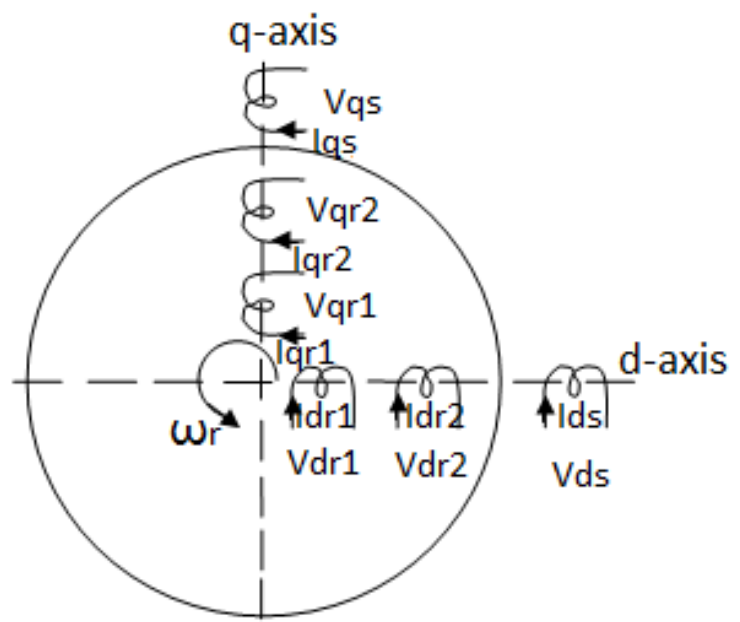

Fig 2: Double-cage model using park transformation in the fixed reference frame $(d, q)$

By adopting the well-known assumptions of the generalized theory of electrical machines, the double-cage induction motor can be described in a reference frame $(\mathrm{d}, \mathrm{q})$ with the following set of differential and algebraic equations [4]. 
$V_{d s}^{e}=R_{s} i_{d s}^{e}+\frac{d \psi_{d s}^{e}}{d t}+\omega_{e} \psi_{q s}^{e}$

$V_{q s}^{e}=R_{s} i_{q s}^{e}+\frac{d \psi_{q s}^{e}}{d t}+\omega_{e} \psi_{d s}^{e}$

$V_{q r 1}^{e}=R_{r 1} i_{q r 1}^{e}+\frac{d \psi_{q r 1}^{e}}{d t}+\left(\omega_{e}-\omega_{r}\right) \psi_{d r 1}^{e}$

$V_{d r 1}^{e}=R_{r 1} i_{d r 1}^{e}+\frac{d \psi_{d r 1}^{e}}{d t}+\left(\omega_{e}-\omega_{r}\right) \psi_{q r 1}^{e}$

$V_{q r 2}^{e}=R_{r 2} i_{q r 2}^{e}+\frac{d \psi_{q r 2}^{e}}{d t}+\left(\omega_{e}-\omega_{r}\right) \psi_{d r 2}^{e}$

$V_{d r 2}^{e}=R_{r 2} i_{d r 2}^{e}+\frac{d \psi_{d r 2}^{e}}{d t}+\left(\omega_{e}-\omega_{r}\right) \psi_{q r 2}^{e}$

The magnetizing flux linkage may then be written as

$$
\begin{aligned}
& \psi_{d s}^{e}=L_{l s} i_{d s}^{e}+L_{m}\left(i_{d s}^{e}+i_{d r 1}^{e}+i_{d r 2}^{e}\right) \\
& \psi_{q s}^{e}=L_{l s} i_{q s}^{e}+L_{m}\left(i_{q s}^{e}+i_{q r 1}^{e}+i_{q r 2}^{e}\right) \\
& \psi_{q r 1}^{e}=L_{l r 1} i_{q r 1}^{e}+L_{m}\left(i_{q s}^{e}+i_{q r 1}^{e}+i_{q r 2}^{e}\right) \\
& \psi_{q r 2}^{e}=L_{l r 2} i_{q r 2}^{e}+L_{m}\left(i_{q s}^{e}+i_{q r 1}^{e}+i_{q r 2}^{e}\right) \\
& \psi_{d r 2}^{e}=L_{l r 2} i_{d r 2}^{e}+L_{m}\left(i_{q s}^{e}+i_{d r 1}^{e}+i_{d r 2}^{e}\right) \\
& \psi_{d r 1}^{e}=L_{l r 1} i_{d r 1}^{e}+L_{m}\left(i_{d s}^{e}+i_{d r 1}^{e}+i_{d r 2}^{e}\right) \\
& \psi_{d m}^{e}=L_{m}\left(i_{d s}^{e}+i_{d r 1}^{e}+i_{d r 2}^{e}\right) \\
& \psi_{q m}^{e}=L_{m}\left(i_{q s}^{e}+i_{q r 1}^{e}+i_{q r 2}^{e}\right)
\end{aligned}
$$

Mutual flux linkage between the stator and inner cage is $\mathrm{L}_{\mathrm{m} 1}$ and between stator and outer cage is $\mathrm{L}_{\mathrm{m} 2}$. Again between outer cage and inner cage is $\mathrm{L}_{\mathrm{m} 12}$. $\mathrm{L}_{\mathrm{m} 12}$ is slightly higher than $\mathrm{L}_{\mathrm{m} 1}$ and $\mathrm{L}_{\mathrm{m} 2}$ but with approximation $\mathrm{L}_{\mathrm{m} 1}=\mathrm{L}_{\mathrm{m} 2}=\mathrm{L}_{\mathrm{m} 12}$. The electromagnetic torque expression can be written as

$$
T_{e}=\left(\frac{3}{2}\right)\left(\frac{p}{2}\right)\left(\psi_{d s}^{e} i_{q s}^{e}-\psi_{q s}^{e} i_{d s}^{e}\right)
$$

Or,

$T_{e}=\left(\frac{3}{2}\right)\left(\frac{p}{2}\right) L_{m}\left[\left(i_{d r 1}^{e} i_{q s}^{e}-i_{q r 1}^{e} i_{d s}^{e}\right)+\left(i_{d r 2}^{e} i_{q s}^{e}-i_{q r 2}^{e} i_{d s}^{e}\right)\right]$

Where,

$$
\omega_{m}=\left(\frac{2}{p}\right) \omega_{r}
$$

\section{PRINCIPLE AND STRATEGY OF THE INDIRECT VECTOR CONTROL}

In case of induction machines, the control is usually performed in the reference frame (d-q) attached to the rotor flux space vector. That's why the implementation of vector control requires information on the modulus and the space angle (position) of the rotor flux space vector. The stator currents of the induction machine are separated into flux- and torque-producing components by utilizing transformation to the d-q coordinate system, whose direct axis $(d)$ is aligned with the rotor flux space vector. That means that the $q$-axis component of the rotor flux space vector is always zero.

The slip difference between the rotor speed and the synchronous speed is given by

$$
\omega_{s l}=\omega_{e}-\omega_{r}
$$

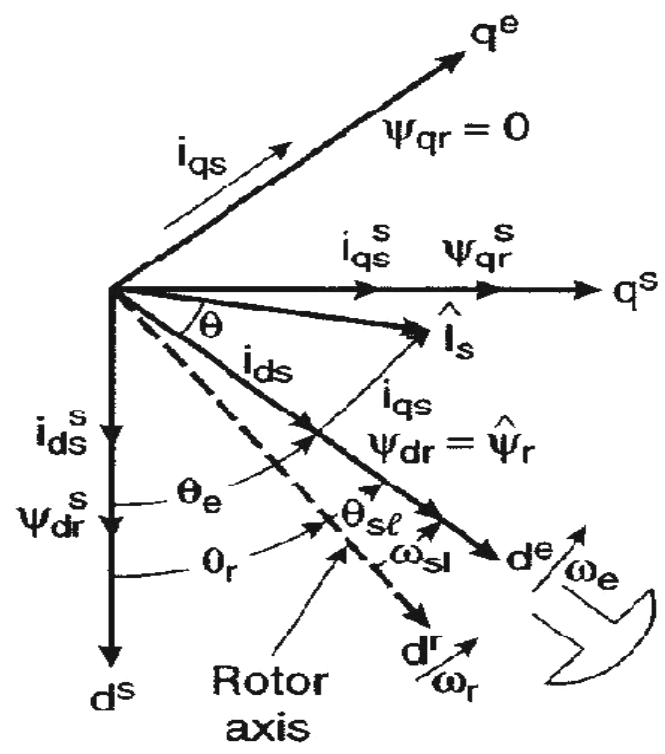

Fig 3: Indirect vector control phasor diagram

In order to ensure decoupling between the stator flux and the torque, the torque component of the current, $\mathrm{i}_{\mathrm{qs}}$, should be aligned with the $\mathrm{q}^{\mathrm{e}}$ axis and the stator flux component of current, $i_{d s}$, should be aligned with the $d^{e}$ axis as shown in Figure 3.

The rotor circuit equations may be written as

$$
\begin{aligned}
& \frac{d \psi_{d r 1}^{e}}{d t}+R_{r 1} i_{d r 1}^{e}-\omega_{s l} \psi_{q r 1}^{e}=0 \\
& \frac{d \psi_{q r 1}^{e}}{d t}+R_{r 1} i_{d r 1}^{e}+\omega_{s l} \psi_{q r 1}^{e}=0 \\
& \frac{d \psi_{d r 2}^{e}}{d t}+R_{r 2} i_{d r 2}^{e}-\omega_{s l} \psi_{q r 2}^{e}=0 \\
& \frac{d \psi_{q r 2}^{e}}{d t}+R_{r 2} i_{q r 2}^{e}+\omega_{s l} \psi_{d r 2}^{e}=0
\end{aligned}
$$

For decoupling control the total rotor flux $\psi_{r}^{e *}$ needs to be aligned with the $\mathrm{d}^{\mathrm{e}}$-axis i.e

$$
\begin{aligned}
& \psi_{r}^{e^{*}}=\psi_{d r}^{e}=\psi_{d r 1}^{e}+\psi_{d r 2}^{e} \\
& \text { And } \quad \psi_{q r}^{e}=\psi_{q r 1}^{e}+\psi_{q r 2}^{e}=0
\end{aligned}
$$


So $\psi_{q r 1}^{e}=0$ and $\psi_{q r 2}^{e}=0$

Now with constant rotor flux the rotor circuit equation can be rewritten as

$i_{d r 1}^{e}=0$

$R_{r 1} i_{q r 1}^{e}+\omega_{s l} \psi_{d r 1}^{e}=0$

$i_{d r 2}^{e}=0$

$R_{r 2} i_{q r 2}^{e}+\omega_{s l} \psi_{d r 2}^{e}=0$

Adding the above equations

$\omega_{s l} \psi_{r}^{e^{*}}=-\left(r_{r 1} i_{q r 1}^{e}+r_{r 2} i_{q r 2}^{e}\right)$

The rotor currents may be written from the magnetizing flux linkage as

$i_{q r 1}^{e}=\frac{i_{q s}^{e}\left(L_{m}^{2}-L_{m} L_{r 2}\right)}{L_{r 1} L_{r 2}-L_{m}^{2}}$

$i_{q r 2}^{e}=\frac{i_{q s}^{e}\left(L_{m}^{2}-L_{m} L_{r 1}\right)}{L_{r 1} L_{r 2}-L_{m}^{2}}$

Now substituting the above values

$\omega_{s l}^{*}=\frac{L_{m} i_{q s}^{e^{*}}\left[\left(L_{r 2}-L_{m}\right) r_{r 1}+\left(L_{r 1}-L_{m}\right) r_{r 2}\right]}{\left(L_{r 1} L_{r 2}-L_{m}^{2}\right) \psi_{r}^{e^{*}}}$

After simplification, electromagnetic torque is

$T_{e}^{*}=\left(\frac{3}{2}\right)\left(\frac{p}{2}\right)\left(\frac{L_{m}}{2}\right)\left(\frac{L_{r 1} L_{r 2}-L_{m}^{2}}{L_{r 1}+L_{r 2}-2 L_{m}}\right) \psi_{r}^{e^{*}} i_{q s}^{e^{*}}(33)$

So $i_{q s}^{e^{*}}=\left(\frac{T_{e}^{*}}{\psi_{r}^{e^{*}}}\right)\left(\frac{8}{3 p L_{m}}\right)\left(\frac{L_{r 1}+L_{r 2}-2 L_{m}}{L_{r 1} L_{r 2}-L_{m}^{2}}\right)$

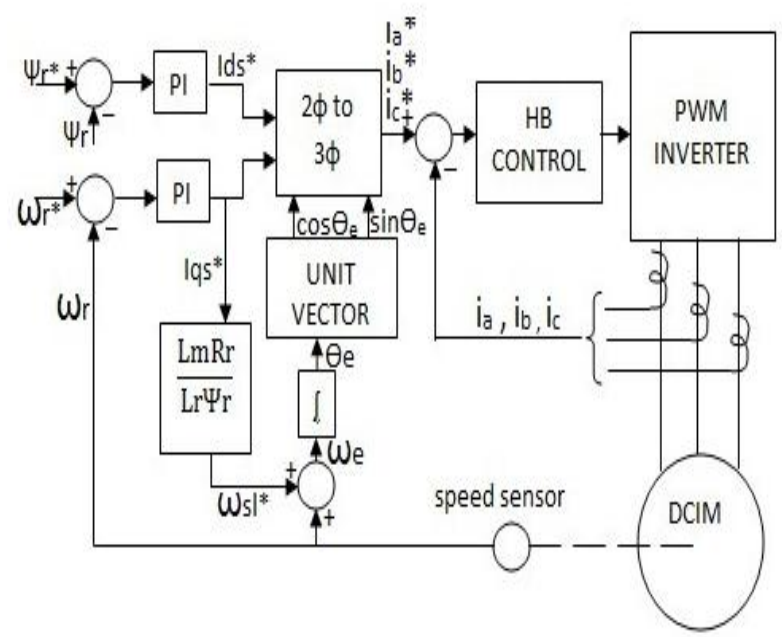

Fig 4:Schemeof indirect vector control method

\section{PRINCIPLE AND STRATEGY OF THE CONSTANT V/f CONTROL}

The principle of constant V/f control requires that, the magnitude and frequency of the voltage applied to the stator of a motor maintain a constant ratio. By this scheme, the magnitude of the magnetic field in the stator is kept at an approximately constant level throughout the operating range. Thus, maximum constant torque producing capability is maintained. However, when the frequency and hence also the voltage are low, the voltage drop across the stator resistance cannot be neglected and must be compensated with boost voltage. At frequencies higher than the rated value, the constant $\mathrm{V} / \mathrm{Hz}$ principle also have to be violated because, to avoid insulation break down, the stator voltage must not exceed its rated value.

The actual rotor speed is compared with its reference value $\omega_{\mathrm{m}} *$ and the error is processed through a PI controller with a limiter to obtain the slip speed command $\omega_{\mathrm{sl}} *$ (within the maximum allowable slip speed of the induction motor).

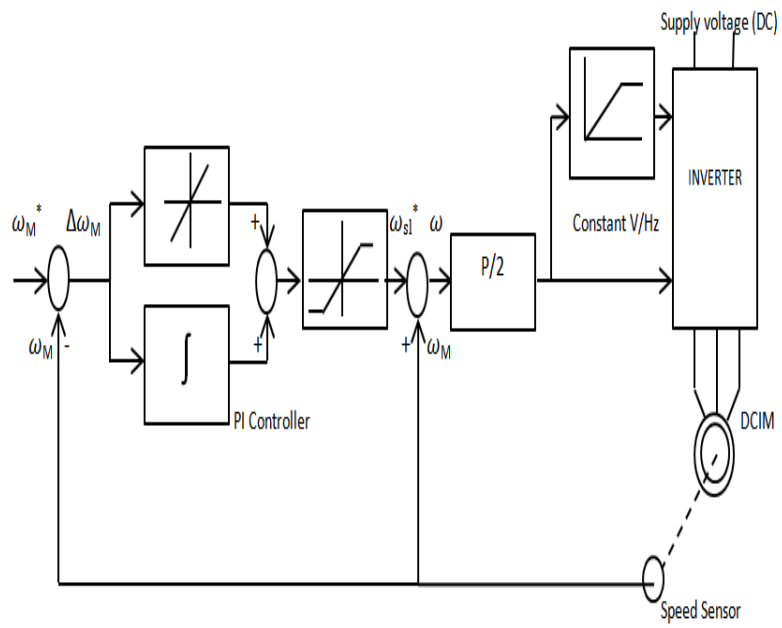

Fig 5:Block-diagram of a V/f Speed Control Loop System

The slip speed command is added to rotor speed to obtain the stator frequency command. Thereafter a Boost voltage is added to the voltage, proportional to stator frequency and the result is processed through a sinusoidal modulator and PWM firing scheme to generate gate pulses that is required for inverter fed induction motor drive.

The expression for maximum torque from the equivalent circuit is

$T_{\max }=\left(\frac{3 P}{4 \omega_{e}}\right)\left(\frac{V_{s}^{2}}{R_{s}+\sqrt{R_{s}^{2}+\left(X_{s}+X_{r}^{\prime}\right)^{2}}}\right) V_{1}$

Again

$T_{\max }=\left(\frac{3 P}{4 \omega_{e}}\right)\left(\frac{K\left(\frac{V_{s}}{f}\right)^{2}}{\frac{R_{s}}{f}+\sqrt{\left(\frac{R_{s}}{f}\right)^{2}+4 \Pi^{2}\left(L_{s}+L_{r}^{\prime}\right)^{2}}}\right)$

Where $X_{r}^{\prime}=$ Equivalent rotor reactance and $L_{r}^{\prime}=$ Equivalent rotor inductance. Determination of boost voltage includes 
* $T_{\max }$ is calculated from the Torque-speed characteristic.

*At a particular frequency, the supply voltage required $V_{1}$ is calculated by using constant $V_{s} / f$ ratio and the actualvoltage $V_{2}$ required for $T_{\max }$ is calculated by using above equation.

*The boost voltage at a particular frequency is calculated by taking the difference between the $\mathrm{V}_{2}$ and $\mathrm{V}_{1}$.

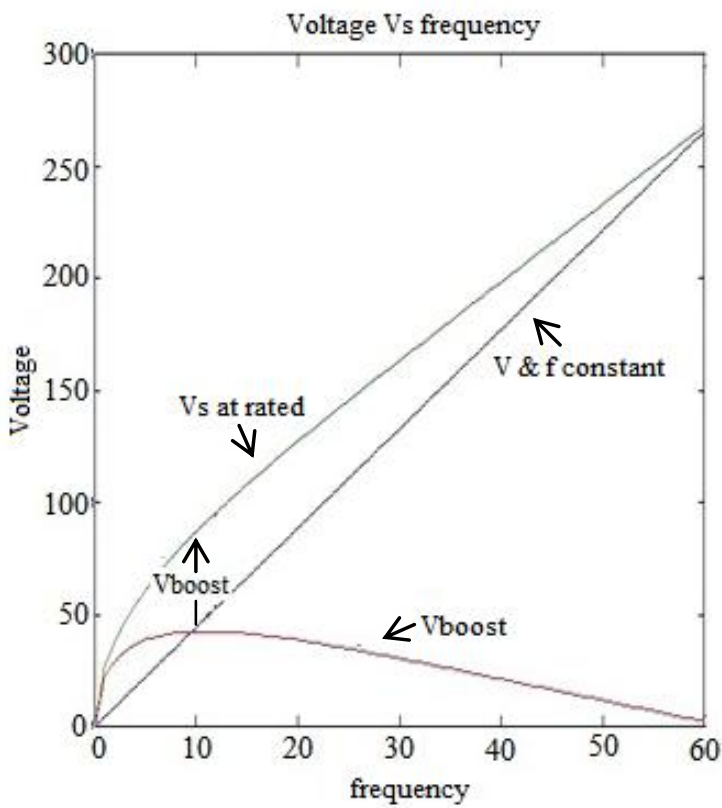

Fig 6: Vboost lookup table programming result

The above result shows the variation of boost voltage with respect to frequency to retain the same maximum torque at low speeds. So v/f ratio is maintained constant below the base speed, except at low frequencies where $\mathrm{v} / \mathrm{f}$ ratio is increased by adding the boost voltage to keep maximum torque constant.

\section{SIMULATION RESULTS AND} ANALYSIS

Simulations were carried out using the software Matlab/Simulink. The mathematical model of the double-cage induction machine, used in this simulation, is given in section II. The motor under investigation is $11 \mathrm{Kw}, 400$-volt, $50 \mathrm{~Hz}, 4$ poles, three phase double squirrel-cage induction motor. The machine parameters are given in the appendix.

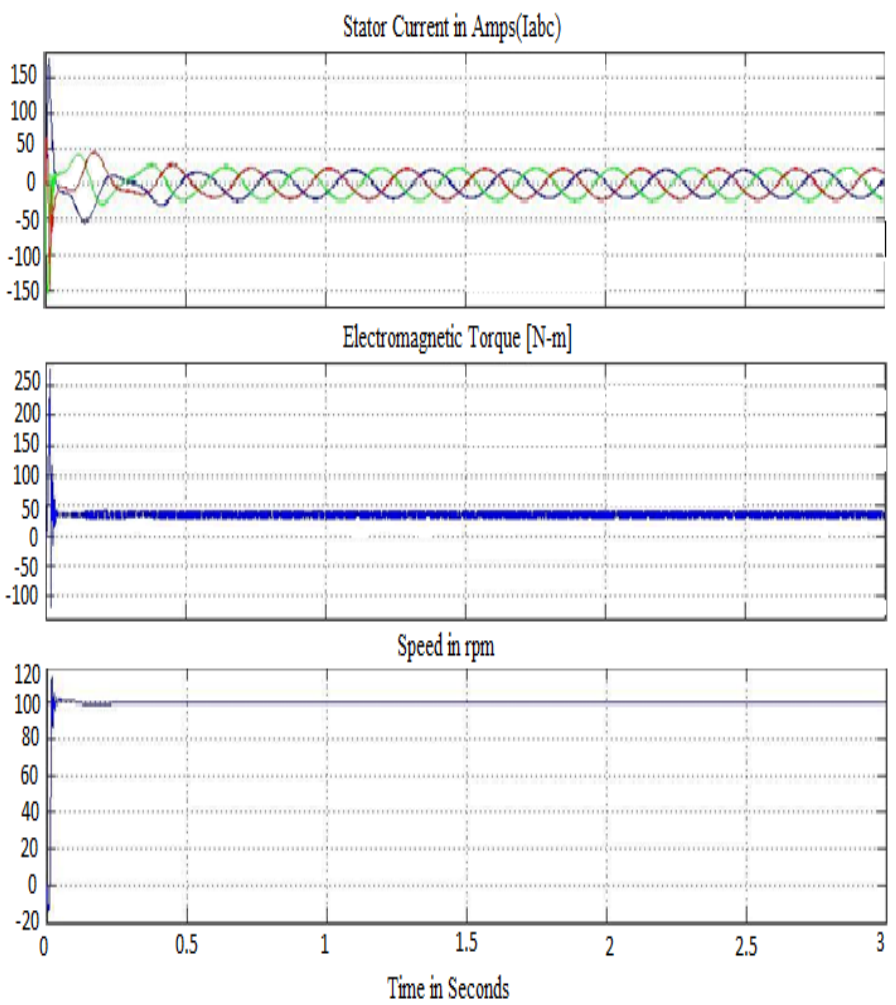

Fig 7: $\mathrm{N}_{\mathrm{r}}{ }^{*}=100 \mathrm{rpm}$ with $50 \%$ full load torque (v/f control with lookup table vboost)

Stator Current In Ampere [abc]
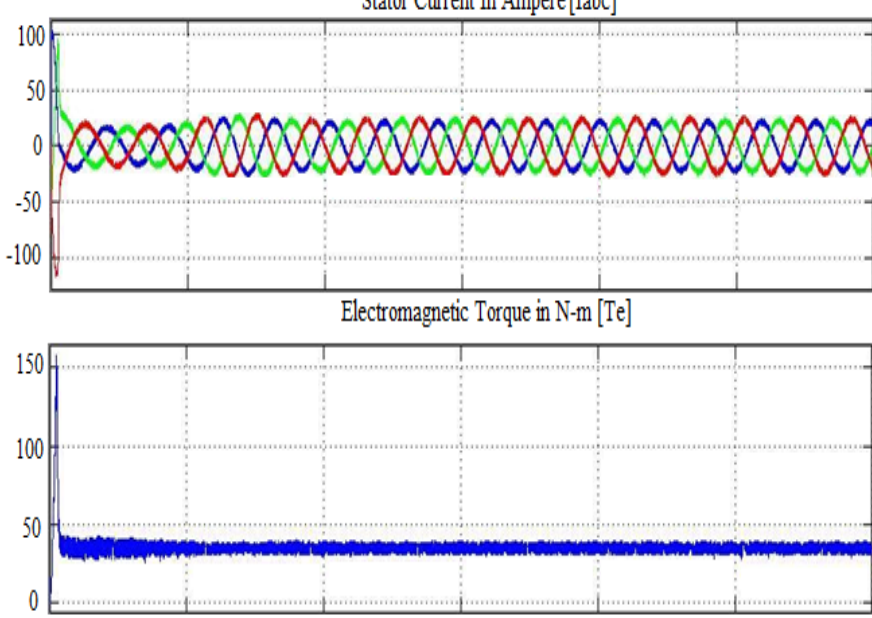

Speed in rpm

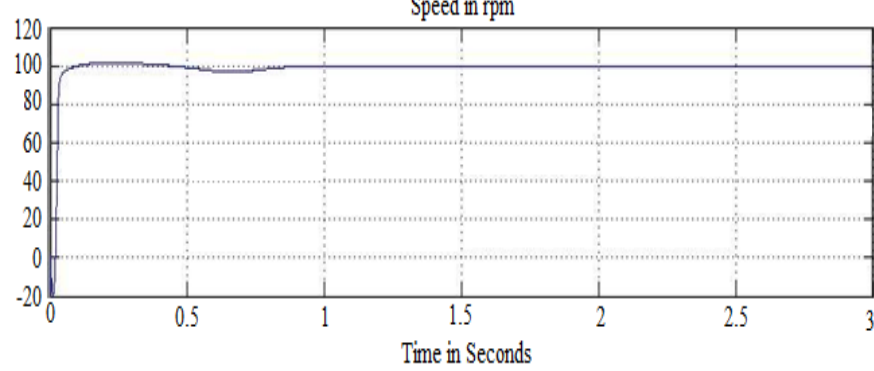

Fig 8: $\mathrm{Nr}^{*}=100 \mathrm{rpm}$ with $50 \%$ full load torque (Indirect vector control) 


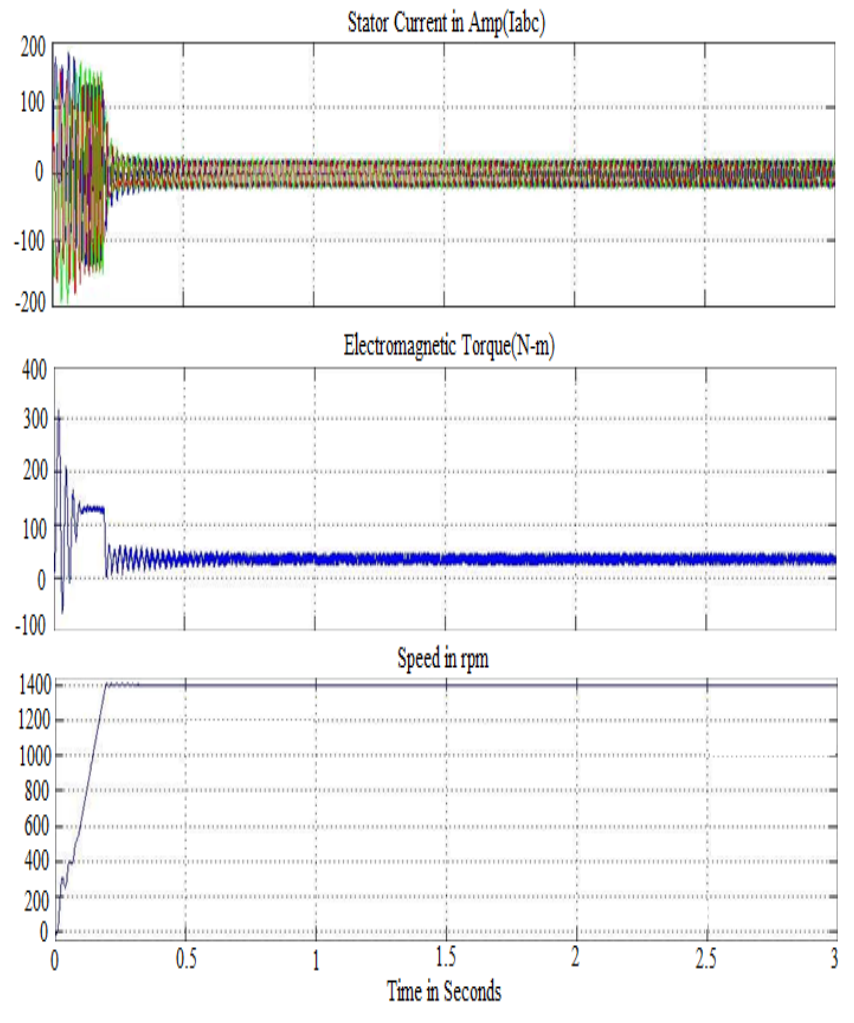

Fig 9: $N_{r}{ }^{*}=1400$ rpm with $50 \%$ full load torque (v/f control with lookup table vboost)

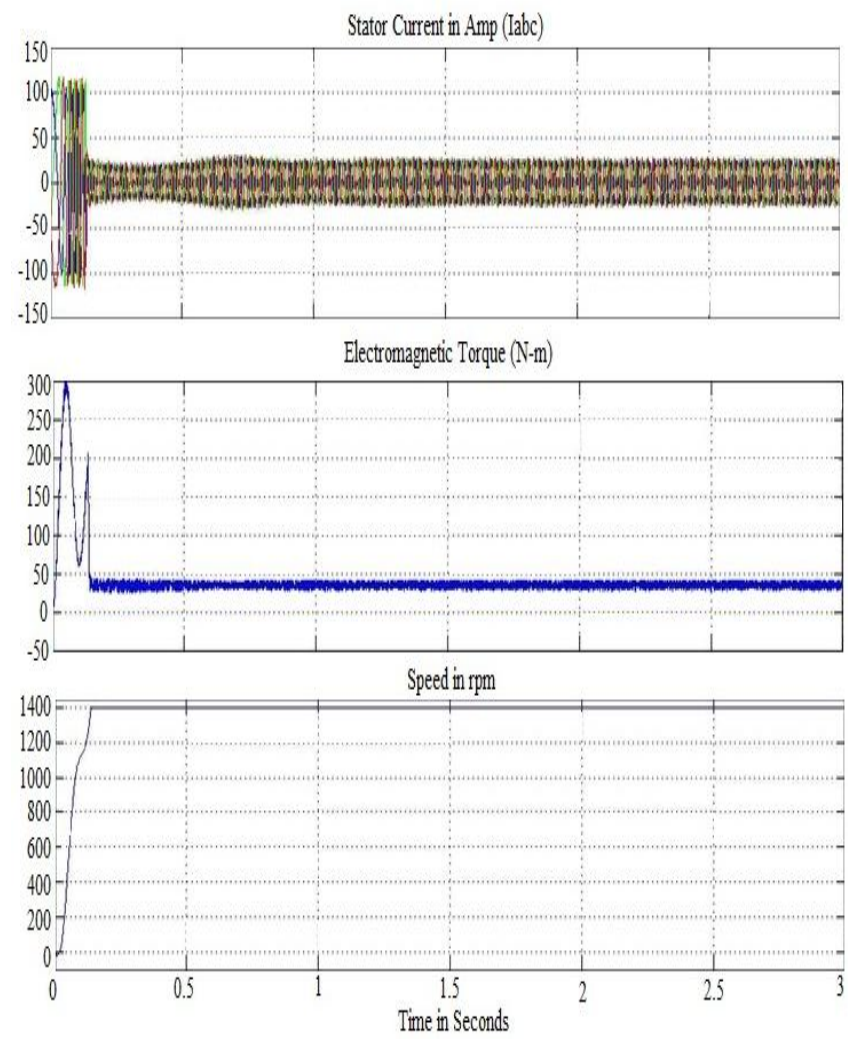

Fig 10: $\mathrm{Nr}^{*}=1400 \mathrm{rpm}$ with $50 \%$ full load torque (indirect vector control)
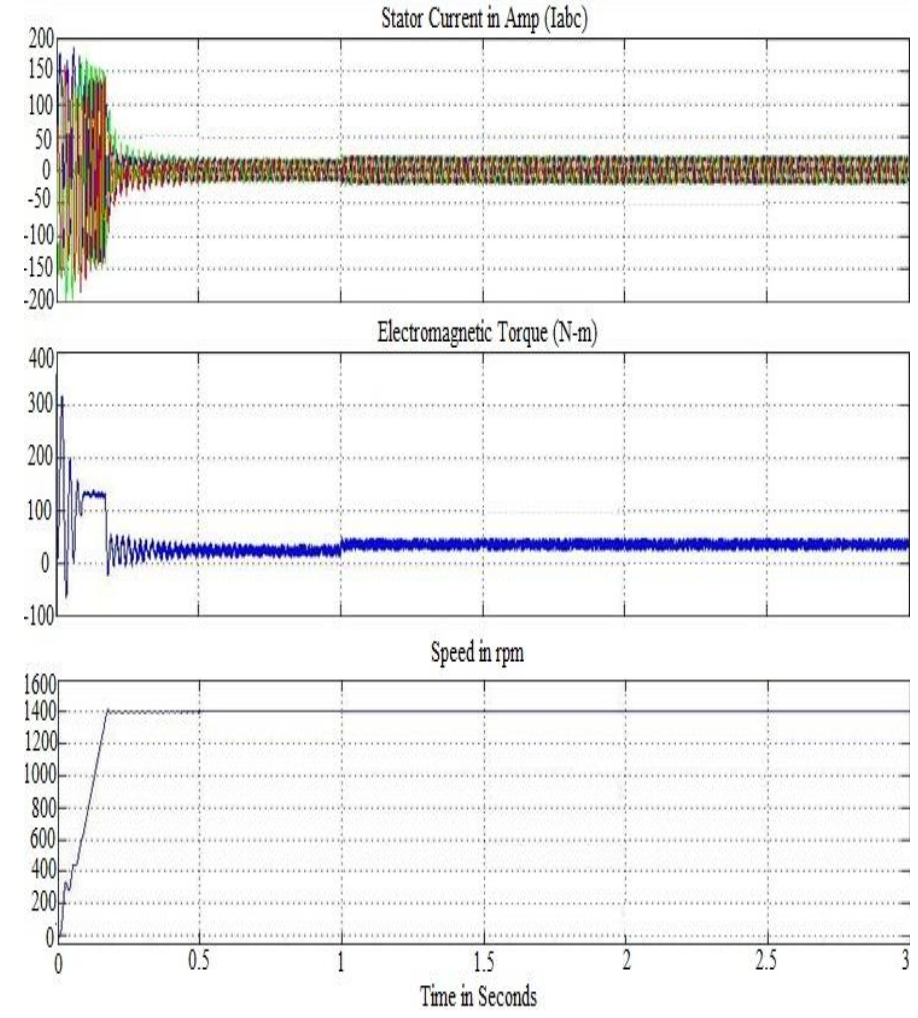

Fig 11: $\mathrm{Nr}^{*}=1400 \mathrm{rpm}$ with $\mathrm{T}_{\mathrm{L}}$ varied from $33 \%$ to $50 \%$ full load torque ( $v / f$ control with lookup table vboost)
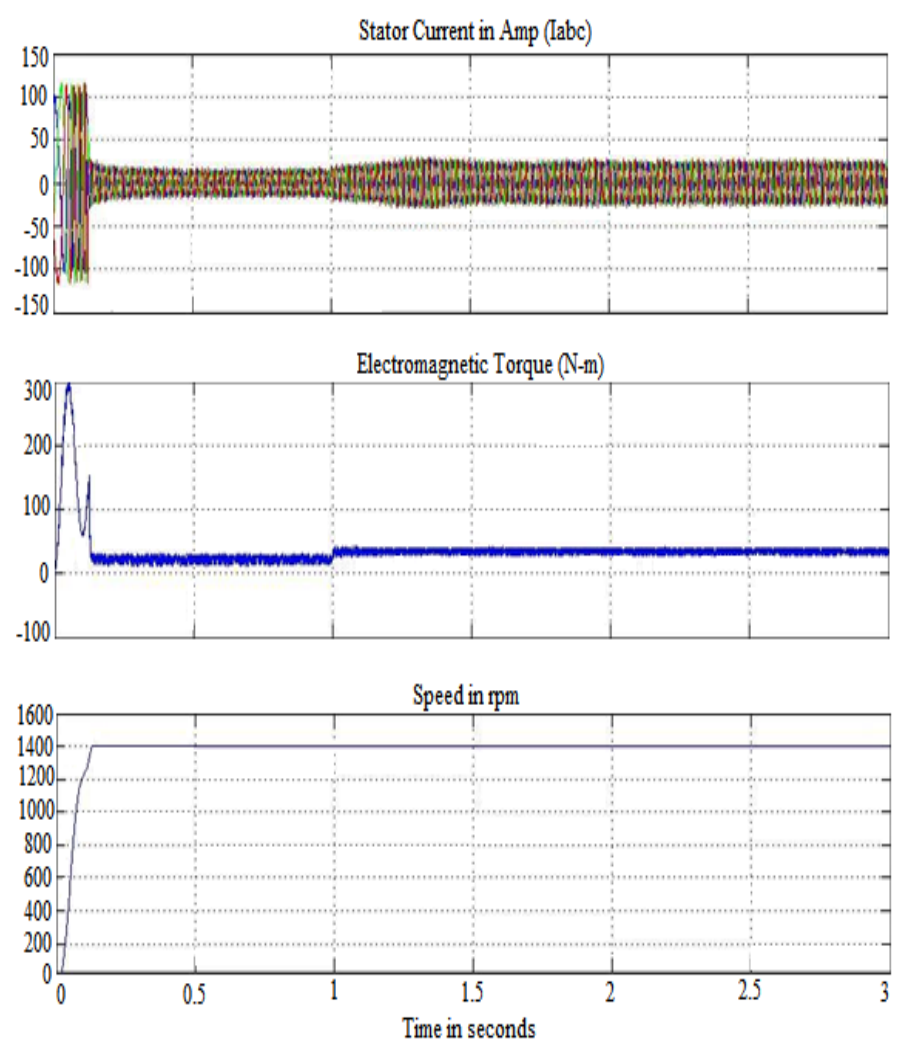

Fig 12: $\mathrm{Nr}^{*}=1400 \mathrm{rpm}$ with $\mathrm{T}_{\mathrm{L}}$ varied from $33 \%$ to $50 \%$ full load torque (indirect vector control) 

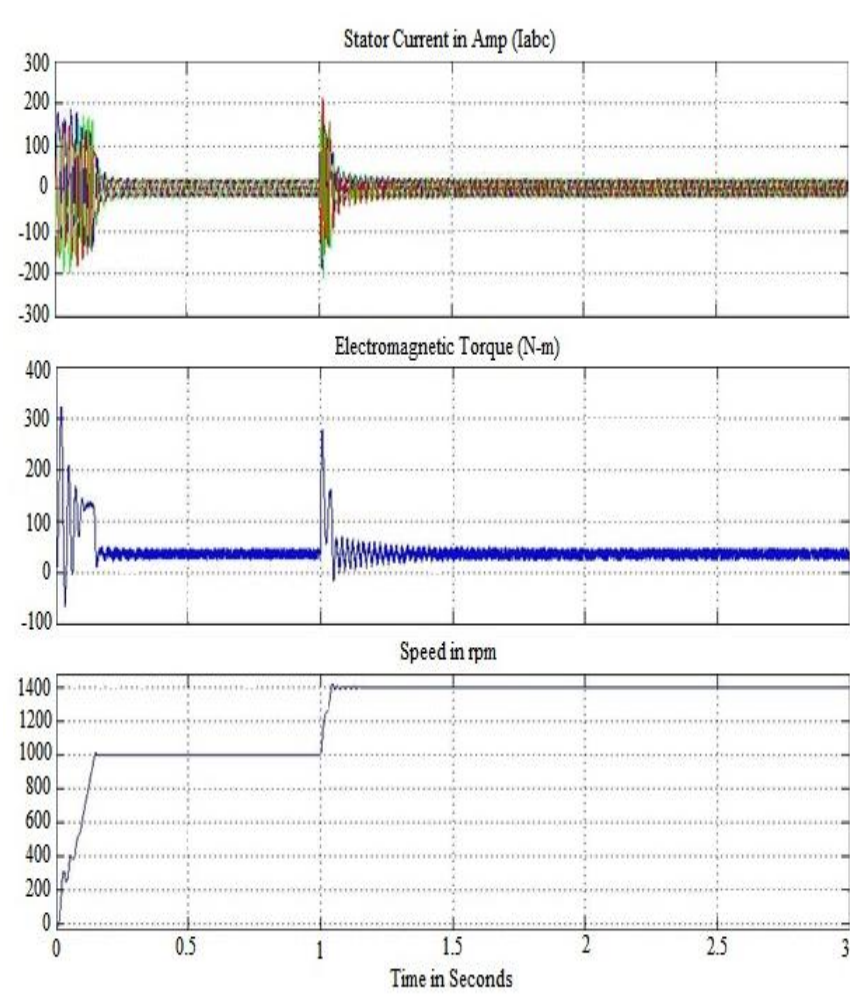

Fig 13: Nr ${ }^{*}$ varied from $1000 \mathrm{rpm}$ to $1400 \mathrm{rpm}$ with $50 \%$ full load torque (v/f control with lookup table vboost)
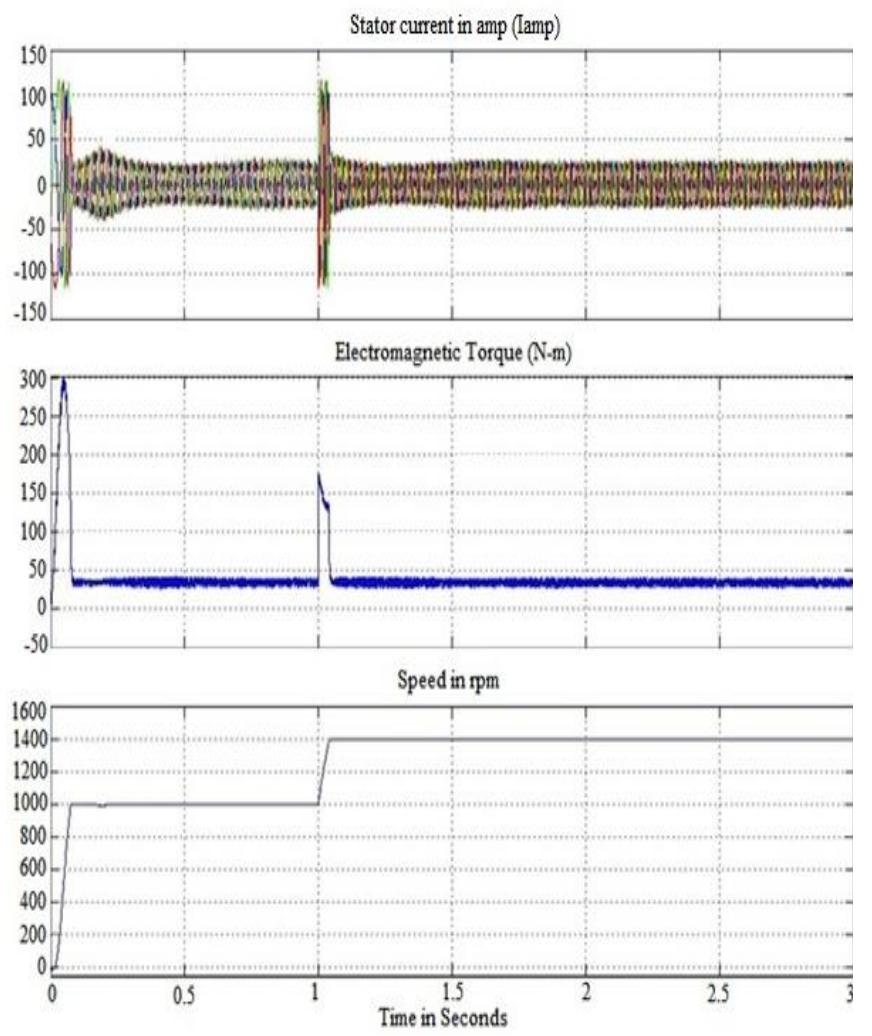

Fig 14: Nr*varied from 1000 rpm to 1400 rpm with $50 \%$ full load torque (indirect vector control)

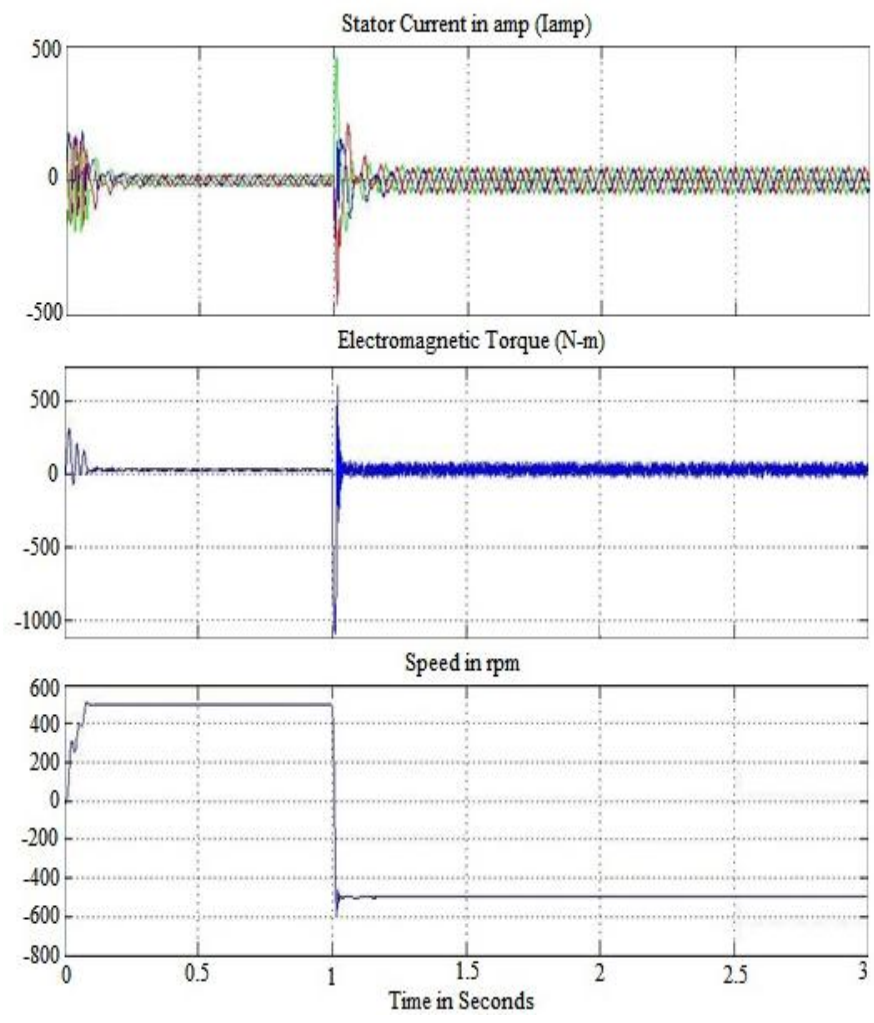

Fig 15: $\mathrm{Nr}^{*}$ varied from $500 \mathrm{rpm}$ to $-500 \mathrm{rpm}$ with $50 \%$ full load torque (v/f control with lookup table vboost)
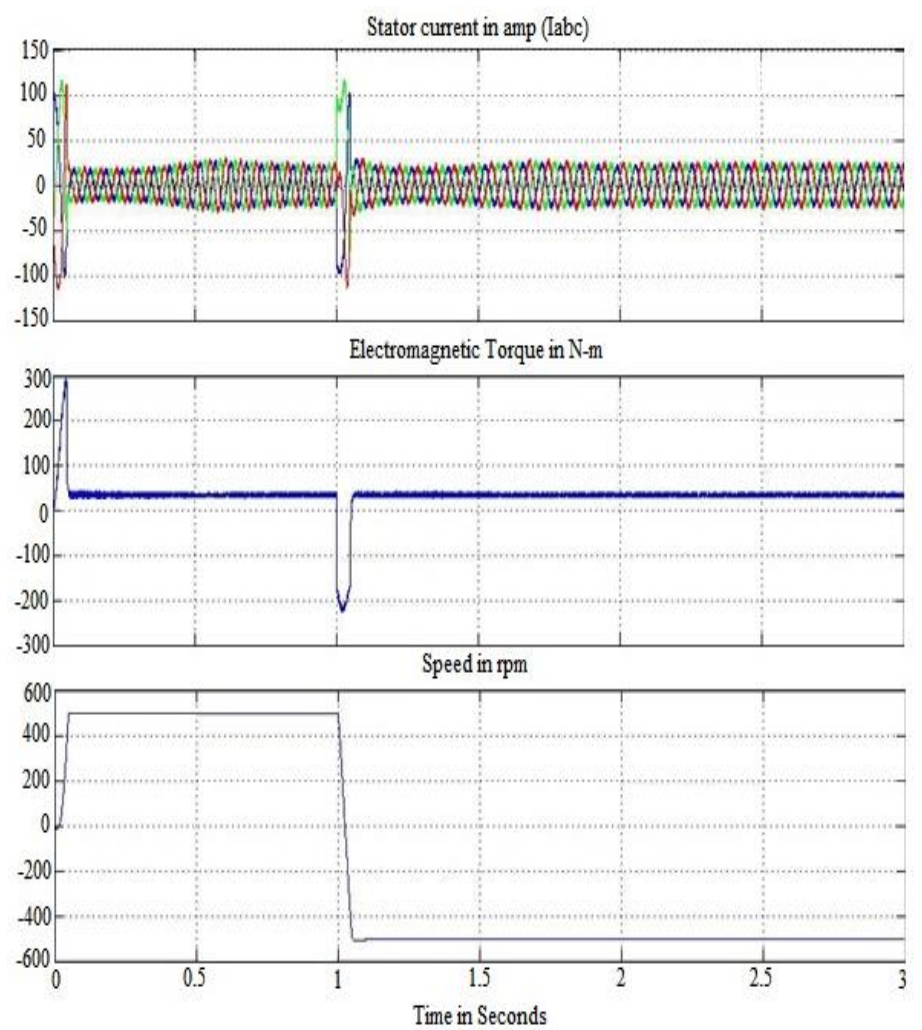

Fig 16: $\mathrm{Nr}^{*}$ varied from $500 \mathrm{rpm}$ to $-500 \mathrm{rpm}$ with $\mathbf{5 0 \%}$ full load torque (indirect vector control) 


\subsection{Constant V/f control with Vboost}

The corresponding simulation results, of the constant V/f control with Vboost of double squirrel-cage induction motor, are shown in Figure 7, Figure 9, Figure 11, Figure 13 and Figure 15, where the curves for the speed, electromagnetic torque and stator currents are given.

\subsection{Indirectvector control}

The corresponding simulation results, of the indirect vector control of double squirrel-cage induction motor, are shown in Figure 8, Figure 10, Figure 12, Figure 14 and Figure 16, where the curves for the speed, electromagnetic torque and stator currents are given.

Table 1. Comparative results for speed of 100 and 1400

\begin{tabular}{|l|l|l|l|}
\hline \multirow{4}{*}{$\begin{array}{c}\text { Speed in } \\
\text { rpm }\end{array}$} & & 100 & 1400 \\
\hline \multirow{4}{*}{$\begin{array}{l}\text { Constant } \\
\text { control }\end{array}$} & $\mathrm{T}_{\mathrm{S}}$ in Nm & 270 & 315 \\
\cline { 2 - 4 } & $\mathrm{I}_{\mathrm{S}}$ in Amp. & 170 & 170 \\
\cline { 2 - 4 } & $\begin{array}{c}\text { Torque } \\
\text { pulsation in Nm. }\end{array}$ & 10 & 22 \\
\cline { 2 - 4 } & $\mathrm{I}_{\mathrm{SS}}$ in Amp. & 22 & 22 \\
\cline { 2 - 4 } & $\mathrm{t}_{\mathrm{SS}}$ in sec. & 0.235 & 0.38 \\
\hline \multirow{4}{*}{$\begin{array}{l}\text { Vector } \\
\text { control }\end{array}$} & $\mathrm{T}_{\mathrm{S}}$ in Nm & 150 & 300 \\
\cline { 2 - 4 } & $\mathrm{I}_{\mathrm{S}}$ in Amp. & 95 & 116 \\
\cline { 2 - 4 } & $\begin{array}{c}\text { Torque } \\
\text { pulsation in Nm. }\end{array}$ & 9 & 12 \\
\cline { 2 - 4 } & $\mathrm{I}_{\mathrm{SS}}$ in Amp. & 25 & 25 \\
\cline { 2 - 4 } & $\mathrm{t}_{\mathrm{SS}}$ in sec. & 0.85 & 0.14 \\
\hline
\end{tabular}

Table 2.Comparative results for varying speed

\begin{tabular}{|c|c|c|c|}
\hline $\begin{array}{l}\text { Speed in } \\
\text { rpm }\end{array}$ & & $\begin{array}{c}1000 \\
\text { To } \\
1400\end{array}$ & $\begin{array}{l}500 \\
\text { To } \\
-500\end{array}$ \\
\hline \multirow{5}{*}{$\begin{array}{l}\text { Const } \\
\text { ant V/f } \\
\text { control }\end{array}$} & $\mathrm{T}_{\mathrm{S}}$ in $\mathrm{Nm}$ & 270 & -600 \\
\hline & $\mathrm{I}_{\mathrm{S}}$ in Amp. & 170 & 450 \\
\hline & $\begin{array}{c}\text { Torque } \\
\text { pulsation in } \mathrm{Nm} \text {. }\end{array}$ & 24 & 100 \\
\hline & $\mathrm{I}_{\mathrm{SS}}$ in Amp. & 22 & 20 to 45 \\
\hline & $\mathrm{t}_{\mathrm{SS}}$ in sec. & 0.17 & 0.16 \\
\hline \multirow{5}{*}{$\begin{array}{l}\quad \text { Indire } \\
\text { ct Vector } \\
\text { control }\end{array}$} & $\mathrm{T}_{\mathrm{S}}$ in $\mathrm{Nm}$ & 175 & -220 \\
\hline & $\mathrm{I}_{\mathrm{S}}$ in Amp. & 115 & 110 \\
\hline & $\begin{array}{c}\text { Torque } \\
\text { pulsation in } \mathrm{Nm} \text {. }\end{array}$ & 12 & 10 \\
\hline & $\mathrm{I}_{\mathrm{SS}}$ in Amp. & 25 & 22 \\
\hline & $\mathrm{t}_{\mathrm{SS}}$ in sec. & 0.042 & 0.055 \\
\hline
\end{tabular}

Table 3.Comparative results for electromagnetic Torque

\begin{tabular}{|c|c|c|c|}
\hline $\begin{array}{l}\text { Speed in } \\
\text { RPM }\end{array}$ & \multicolumn{3}{|c|}{1400} \\
\hline \multirow{6}{*}{$\begin{array}{l}\mathrm{T}_{\mathrm{L}} \text { in } \mathrm{Nm} . \\
33 \% \text { to } 50 \% \\
\text { of Full Load } \\
\text { Torque }\end{array}$} & \multirow{3}{*}{$\begin{array}{c}\text { Constant } \\
\text { V/f control }\end{array}$} & $\begin{array}{c}\text { Torque } \\
\text { pulsation in } \mathrm{Nm} \text {. }\end{array}$ & 25 \\
\hline & & $\mathrm{I}_{\mathrm{SS}}$ in Amp. & 22 \\
\hline & & $\mathrm{t}_{\mathrm{SS}}$ in $\mathrm{sec}$ & 0.05 \\
\hline & \multirow{3}{*}{$\begin{array}{l}\text { Indirect } \\
\text { Vector } \\
\text { control }\end{array}$} & $\begin{array}{c}\text { Torque } \\
\text { pulsation in } \mathrm{Nm} \text {. }\end{array}$ & 12 \\
\hline & & $\mathrm{I}_{\mathrm{SS}}$ in Amp. & 25 \\
\hline & & $\mathrm{t}_{\mathrm{SS}}$ in $\mathrm{sec}$ & 0.05 \\
\hline
\end{tabular}

Table 4.Performance analysis

\begin{tabular}{|c|c|c|}
\hline \multirow{2}{*}{ Speed in rpm } & \multicolumn{2}{|c|}{ Power factor } \\
\cline { 2 - 3 } & $\begin{array}{c}\text { v/f speed control with } \\
\text { lookup table Vboost }\end{array}$ & $\begin{array}{c}\text { Indirect } \\
\text { vector control }\end{array}$ \\
\hline 1400 & 0.765 & 0.89 \\
\hline 1200 & 0.76 & 0.887 \\
\hline 1000 & 0.754 & 0.885 \\
\hline 800 & 0.74 & 0.88 \\
\hline 600 & 0.72 & 0.85 \\
\hline 400 & 0.685 & 0.82 \\
\hline 200 & 0.57 & 0.74 \\
\hline 100 & 0.43 & 0.68 \\
\hline
\end{tabular}

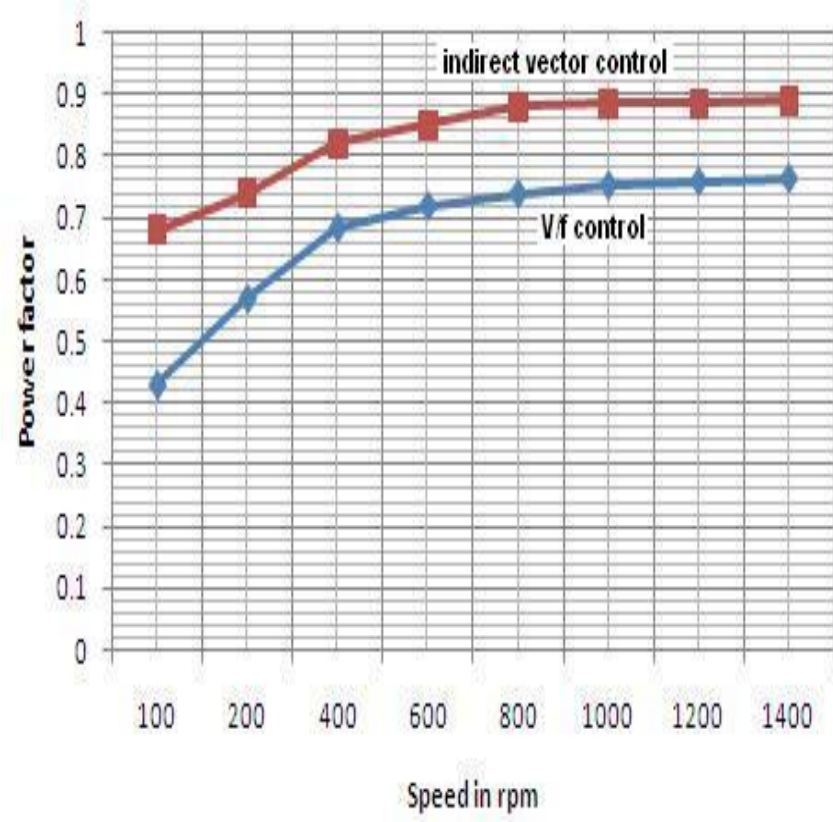

Fig 17: Graphical analysis of power factor vs speed

\section{CONCLUSION}

The simulation results show the excellent response achieved with the indirect vector control method as compared to constant $\mathrm{v} / \mathrm{f}$ control method even at extremely low frequency in terms of low torque pulsation, less stator current ripple and lower steady state time. Simulation results validate the effectiveness of the proposed indirect vector control method during speed reversal operation over constant v/f control method that suffers from high transient instability. The performance analysis of induction motor has shown that indirect vector control method has a good dynamic behavior with improved power factor over the whole frequency range.

\section{APPENDIX-MOTOR DATA}

$11 \mathrm{Kw}, \quad 400 \mathrm{~V}, \quad 1480 \mathrm{rpm}, \quad \mathrm{R}_{\mathrm{S}}=0.2113 \Omega, \quad \mathrm{X}_{\mathrm{LS}}=0.7913 \Omega$, $\mathrm{R}_{1}=0.4226 \Omega, \quad \mathrm{X}_{\mathrm{Lr} 1}=1.7004 \Omega, \mathrm{R}_{2}=1.6598 \Omega, \mathrm{X}_{\mathrm{Lr} 2}=0.7913 \Omega$, $\mathrm{X}_{\mathrm{m}}=\mathrm{X}_{12}=26.096 \Omega, \mathrm{J}=0.11 \mathrm{~kg} . \mathrm{m}^{2}, \mathrm{P}=4$. 


\section{NOMENCLATURE}

Vs : Stator voltage per phase (V).

$V_{d s}^{e}: \mathrm{d}$-axis stator voltage $(\mathrm{V})$.

$V_{q s}^{e}:$ q-axis stator voltage $(\mathrm{V})$.

Vr2 :Rotor outer voltage per phase (V).

Rs: Stator resistance.

R1 : Inner-cage rotor resistance.

R2 : Outer-cage rotor resistance.

Ls : Stator cyclic inductance $(\mathrm{H})$.

$\mathrm{L}_{\mathrm{Lr} 1}$ : Rotor inner leakage inductance $(\mathrm{H})$.

L : Rotor outer Leakage inductance $(\mathrm{H})$.

L12 : Mutual inductance between two rotor cages $(\mathrm{H})$.

Lm : Magnetizing inductance $(\mathrm{H})$.

P: Number of poles.

$\mathrm{TL}$ : Electromagnetic torque and load torque $(\mathrm{Nm})$.

\section{REFERENCES}

[1] VAS, P., "Electric machines and drives. A space-vector theory approach", (Clarendon Press, Oxford, 1992).

[2] J.Pedra,F.Corcoles and L. Sainz, "Effects of unsymmetrical voltage sags on squirrel-cage induction motors" IET Gener. Transm. Distrib., Vol. 1, No. 5,September 2007, pp. 769-775.

[3] Stephen J. Chapman, "Electric machinery fundamentals", McGraw-Hill,1991.

[4] Jukov V., "Short-circuit in electric system nodes with complex load", MEI, Moscow, 1994.

[5] E. Levi and D. Rauski, "Modelling of deep-bar and double-cage self-exicited induction generators for windelectricity generation studies," ELSEVIER Electric Power Systems Research, 27(1993), pp. 73-81.

[6] D. O'Kelly and Simons, "Introduction to Generalised Electrical Machine Theory”, McGraw-Hill, 1968.

[7] Mohan, N. "Advanced Electric Drives. Analysis, Control and Modeling using Simulink ${ }^{\circledR}$ ", MNPERE, 2001.

[8] Adkins, B. "The General Theory of Electrical Machines" Chapman \& Hall Ltd, 1962.

[9] B. ArunaKumari, K. Naga Sujatha, K.Vaisakh, "Assessment of Stresses On Induction Motor
[10] Under Different Fault Conditions",Journal of Theoretical and Applied Information Technology, 2009, pp. 772-779

[11] W. Shepherd and J. Stanway, "An experimental closedloop variable speed drive incorporating a thyristor driven induction motor," IEEE Trans. Ind. Gen. Applicat., vol. IGA-3, pp. 559-565, Nov./Dec. 1967.

[12] A. Abbondanti, "Method of flux control in induction motors driven by variable frequency, variable voltage supplies," in Proc. IEEE-IAS Int. Semi-Annual Power Conversion Conf., 1977, pp. 177-184.

[13] K. Koga, R. Ueda, and T. Sonoda, "Constitution of V/f control for reducing the steady state speed error to zero in induction motor drive system," in Conf. Rec. IEEEIAS Annu. Meeting, 1990, pp. 639-646.

[14] I. Takahashi, T. Noguchi, A new quick response and high efficiency control strategy of an induction motor, in: Conf. Rec. IEEE-IAS Annu. Meeting, 1985, 495-502.

[15] M. Depenbrock, Direct self-control for high dynamics performance of inverter feed a.c. machines, ETZ Arch. 7 (7) (1985) 211-218.

[16] I. Boldea, S.A. Nasar, Torque vector control (TVC)—a class of fast and robust torque, speed and position digital controllers for electric drives, in: Conf. Rec. EMPS'88, vol. 15, 1988, 135-148.

[17] D. Casadei, F. Profumo, G. Serra, A. Tani, FOC and DTC: two viable schemes for induction motors torque control, IEEE Trans. Power Electron. 17 (September) (2002) 779-787.

[18] P. Pohjalainen, P. Tiitinen, J. Lalu, The next-generation motor control method-direct torque control, DTC, in: Conf. Rec. EPE'94, 1994, 115- 120.

[19] J.-K. Kang, S.-K. Sul, New direct torque control of induction motor for minimum torque ripple and constant switching frequency, IEEE Trans. Ind. Appl. 35 (September/October) (1999) 1076-1082.

[20] B.H. Kenny, R.D. Lorenz, Stator and rotor flux based deadbeat direct torque control of induction machines, in: Conf. Rec. IEEE-IAS Annu. Meeting, vol. 1, 2001, 133139. 